\title{
Kommunalreformen og kommunernes interne organisering og styring
}

\author{
Marius Ibsen, Ph.d.-studerende ved Syddansk Universitet og bl.a. tidligere kommunal- \\ direktør i Gladsaxe Kommune
}

Indledning

Artiklen beskriver udviklingen i kommunernes interne organisation, forsøger at vurdere, i hvilken grad organisationsændringerne siden 2007 kan forklares af kommunalreformen og undersøger på et punkt, om ændringerne virker som tilsigtet.

Mange kommuner fik først i 1970 et større administrativt apparat. Dette blev typisk opbygget som forholdsvist selvstændige forvaltninger, knyttet til de enkelte udvalg. Frem til omkring år 2000 skete der en konsolidering. Der blev færre forvaltninger, og den administrative organisation afspejlede ikke længere nødvendigvis den politiske.

I forbindelse med og efter kommunalreformen har diskussionen om kommunernes administration drejet sig dels om valget af overordnet ledelse (forvaltningsmodel eller direktionsmodel), dels om graden af decentralisering. Status i dag er, at der er en stærkere koordinering på tværs, og at mellem en tredjedel og halvdelen af kommunerne (afhængigt af definitionen) har en egentlig direktionsmodel. Men forvaltningsmodellen lever i bedste velgående, om end afsvækket. Der er i alle kommuner sket en betydelig decentralisering - dog med variationer.

Det er vanskeligt præcist at eftervise, i hvilken grad ændringer har forbindelse til kommunalreformen. Men kommuner, der blev sammenlagt, har en signifikant større tilbøjelighed til at have en direktion. Og det forekommer sandsynligt, at reformens vægt på at øge helhedstækningen og sikre bedre vilkår for strategisk ledelse er en væsentlig baggrund for ændringerne. Det kan tilmed sandsynliggøres, at i alt fald indførelsen af en direktion virker som tilsigtet. At ændringerne, som følge af kommunalreformen, ikke er mere omfattende end de er, må tilskrives, at udvalgsstyret består. Der var også andre hensyn i kommunalreformen end overordnet ledelse. 


\section{Artiklens formål}

Hovedtemaet for dette nummer af Politik er, hvilke ændringer det danske kommunestyre har gennemgået siden kommunalreformen og måske som følge af reformen. Et af emnerne er organisering og styring. Det er et meget interessant emne, dels i sig selv, dels fordi det rummer et paradoks. Alle andre sider af den kommunale virksomhed - opgaver, størrelse, finansiering - blev grundigt reformeret. Men den politiske og administrative organisation var som før. Udvalgsstyret forblev uændret, og man lod - som hidtil - være med at regulere den administrative organisation.

Uanset at organisation og styring ikke blev taget op med kommunalreformen, kunne de store ændringer af kommunernes størrelse og opgaver naturligvis udmærket tænkes at have en effekt på kommunernes administrative opbygning og ledelsesformer. Her støder man imidlertid på den vanskelighed, at der ikke er systematiske sammenligninger over en længere tidsperiode. Der er nok skrevet en del om emnet, så det er muligt i grove træk at tegne et billede af udviklingen. Men der er ikke data, som muliggør en sammenligning af kommunalreformen før og efter.

Med disse begrænsninger in mente har artiklen to formål. Først tegnes et billede af, hvordan den administrative organisation har udviklet sig i danske kommuner siden 1970. Dernæst beskrives hovedlinjerne i den kommunale organisation i dag. I den forbindelse diskuteres det, om de ændringer, der har været, kan antages at have været en følge af kommunalreformen, eller om de snarere skyldes andre forhold såsom den statslige styring eller modebevægelser i den administrative verden. I fortsættelse heraf undersøges det, om især én af de organisatoriske ændringer har virket som tænkt: Det drejer sig om etableringen af direktionsmodeller. Hovedidéen i direktionsmodellen er at sikre helhed og koordinering på tværs af de kommunale forvaltningsområder (Bækgaard 2013). På det økonomiske område må helhed og koordinering formodes at være ensbetydende med stærkere styring og dermed blandt andet et større skattefinansieret driftsresultat. Spørgsmålet i artiklen er, om denne effekt kan eftervises.

\section{Udviklingen af den administrative organisation i kommunerne}

Indtil 1970 var den kommunale administration beskeden i de store kommuner og næsten ikke eksisterende i de små (Blom-Hansen m.fl. 2012). Udvalgene traf de fleste og i alt fald alle væsentlige beslutninger. Forvaltningens opgave var at sørge for ekspeditionerne og bogholderiet.

Den første kommunalreform i 1970 betød, at kommunerne blev langt større, fik flere opgaver og også større frihed til at løse dem. Derfor blev der behov for en egentlig administrativ organisation. Der opstod i den forbindelse i alt fald tre spørgsmål: 
a) Skulle administrationen så at sige afspejle den politiske organisation, så der for hvert udvalg var en forvaltning og for hver forvaltning et udvalg?

b) Hvilke forvaltningsenheder skulle der være, og hvordan deltes arbejdet mellem dem? Skulle man lægge hovedvægten på faglige enheder (typisk benævnt forvaltninger), eller var det bedre med en blanding af sådanne enheder og tværgående afdelinger for personale, jura og lignende?

c) Hvordan burde koordinationsopgaverne, for eksempel vedrørende økonomistyringen, tilrettelægges?

Svarene på disse spørgsmål var i første omgang ret enkle. Der blev etableret en forvaltning nogenlunde for hvert udvalg. En af disse var knyttet til økonomiudvalget og blev ledet af kommunaldirektøren. Forvaltningerne var ret selvstændige. Koordinationen blev varetaget dels af kommunaldirektøren, ikke mindst hvad angår det økonomiske, dels via et chefgruppemøde. Dette var dog overvejende et informationsformidlende forum. Koordinationen i den kommunale ledelse var svag og sektoriseringen udbredt (Flohr Nielsen 1985).

Udviklingen siden da kan opdeles i to faser, med et skillepunkt omkring år 2000. Fra 1970 til slutningen af 1990erne skete der ændringer af alle de tre aspekter af organisationen, der er nævnt ovenfor. Den forvaltningsmæssige organisation blev i betydeligt omfang løsrevet fra den politiske (Ejersbo 1998). Det skyldtes til dels, men ikke kun, at de før ganske tætte lovmæssige bindinger på udvalgsstrukturen stort set blev ophævet i 1988. Der blev færre forvaltningsmæssige enheder end tidligere, og arbejdsdelingen mellem dem kom til at variere langt mere end før. Men kan tale om en konsolidering (Ejersbo 1998, Ryom Villadsen 2013).

Konsolideringen blev ledsaget af en betydeligt stærkere koordinering. Morten Balle Hansen undersøgte i midten af 1990erne chefgruppemødet og nåede til, at dets rolle havde udviklet sig meget. Han fandt, at der var sket en mobilisering om omkostningsstyring og strammere budgetdisciplin, og konklusionen var: "Chefgruppemødet er i mange kommuner blevet et forum, hvor den administrative ledelse træffer en række kollektivt bindende beslutninger, som man derefter som administrative chefer er forpligtet til at forsvare" (Balle Hansen 1998).

Ændringerne siden og især i forbindelse med kommunalreformen er beskrevet dels af Peter Kragh Jespersen (i Hansen et al. 2008), dels af Martin Bækgaard (2010). Der kan også henvises til Blom-Hansen et al. (2012). Kragh Jespersen diskuterer - med afsæt i et notat fra Kommunernes Landsforening - de organisatoriske overvejelser i forbindelse med kommunalreformen og beskriver 
den administrative opbygning i kommunerne lige efter reformen. Han tager udgangspunkt i, at "kommunalreformen har været en oplagt lejlighed til at arbejde med den kommunale administrative struktur som strategisk middel til at opnå funktionalitet og/eller øget legitimitet hos politikere og borgere" (Hansen et al. 2008, 91).

Ifølge kommunaldirektørernes svar på et spørgeskema, der blev udsendt i efteråret 2006, var de vigtigste hensyn bag valget af organisering helhed og sammenhæng i opgavevaretagelsen, øget strategisk kapacitet og klar kompetence- og ansvarsfordeling. Øget inddragelse af borgere og overensstemmelse med den politiske struktur spillede derimod en beskeden rolle i overvejelserne.

Kragh Jespersen sondrer på baggrund af svarene på spørgeskemaet mellem flere typer af organisering end forvaltningsmodel/direktionsmodel, men konkluderer dog, at 70 procent har bevaret fagforvaltninger under en eller anden form. De fleste af de resterende kommuner arbejder - siger Kragh Jespersen - typisk med direktioner uden fagansvar i kombination med selvstændige institutioner og driftsenheder, nogenlunde svarende til, hvad der her kaldes en direktionsmodel.

Bækgaard beskriver på grundlag af data indsamlet fra kommunale hjemmesider og kommunalhåndbogen ændringerne i antallet af udvalg og forvaltninger fra 2005-2010. Han skriver:

\footnotetext{
"Konklusionen er, at kommunalreformen både på kort og på længere sigt har ledt til en stigning i antallet af udvalg og fagforvaltninger i kommunerne som helhed. Der kan imidlertid ikke som på kort sigt konstateres signifikante forskelle på sammenlægningskommuner og fortsætterkommuner på længere sigt, og sammenlægningsprocesserne udgør således kun på kort sigt (2007) en forklaring på udviklingen. På længere sigt skal stigningen i antallet af udvalg og forvaltninger i stedet tilskrives ændringerne i kommunernes indbyggertalsmæssige størrelse og i deres opgaveportefølje" (s.42).
}

\section{Den kommunale organisation i dag}

\section{Indledning}

Som det også fremgår af beskrivelsen af ændringerne omkring og lige efter kommunalreformen, har den kommunale diskussion om organisation delvist et andet fokus end tidligere. Antallet af forvaltningsenheder ændrer sig i takt med størrelse og opgaver, men den konsolidering, der fandt sted før årtusindskiftet, er ikke fortsat. Paralleliteten mellem den administrative og politiske organisation debatteres heller ikke længere. 
To emner har til gengæld været centrale. Det ene er arbejdsdelingen og de styringsmæssige relationer mellem den centrale ledelse og de decentrale enheder - skoler, plejehjem og daginstitutioner (Klaudi Klausen og Christoffersen, 2012). Det andet er forvaltningens og den øverste ledelses organisering, hvilket kan opfattes som en fortsættelse af diskussionen om den tværgående koordinering. Man har talt om to modeller: Forvaltningsmodel og direktionsmodel. Der tales også undertiden om en "koncernmodel" (Klaudi Klausen 2014). Der er i alt fald det rigtige heri, at der er mellemformer, som det også fremgår af det empiriske materiale i denne artikel.

\section{Forvaltningsmodel eller direktionsmodel?}

Forvaltningsmodellen er den traditionelle, der er beskrevet ovenfor. Kommunens administration er opdelt $\mathrm{i}$ et antal forvaltninger, som hver for sig ledes af en direktør/forvaltningschef med ansvar såvel for forberedelsen af politiske beslutninger som for den efterfølgende udførelse. Der vil normalt være en tværgående koordination i et chefmøde eller direktørmøde under kommunaldirektørens forsæde.

Direktionsmodellen kan opfattes som en forstærkelse af det chefmøde, der udviklede sig efter 1970, så direktionen principielt er en ledelse for hele kommunen og alle afdelinger refererer til den. Den har et fælles ansvar for betjeningen af det politiske niveau. Ofte er etableringen af en direktion med overordnet ansvar kombineret med en decentralisering af ansvar til afdelinger/centre/områder.

Formodningen er, at sektorsynspunkter vil slå stærkere igennem i en forvaltningsmodel, mens der i en direktionsmodel vil blive lagt mere vægt på den tværgående koordinering og den fælles overordnede politik. Bækgaard et al. (2009) sammenfatter KL's opfattelse af formålet med direktionsmodellen således: "at mindske sektoriseringen, øge helhedstækningen og sikre bedre vilkår for strategisk ledelse” (Bækgaard et al. 2009, p.217). Bækgaard (2013) har da også vist, at organisationsformen har betydning, såvel for kommunikationsmønstret mellem ledende embedsmænd og borgmester/udvalgsformænd som for forvaltningens indflydelse.

Som altid, når det drejer sig om organisation, kan virkeligheden ikke opdeles i teoriens skarpt definerede kategorier. Nok findes de rene modeller, men der er også mange mellemformer. Det rejser spørgsmålet om, hvordan modellerne mere præcist defineres. Det beror både på, hvad teorien egentlig går ud på og på, hvad der lader sig måle. Bækgaard (2013) lægger vægt på driftsansvaret:

"Hvor forvaltningsmodellen har fokus på, at medlemmerne af det administrative lederskab (på nær kommunaldirektøren) har en organisatorisk tilknytning til et kommunalt sektorom- 
råde, er hovedideen i direktionsmodellen at sikre helhed og koordination på tværs af de kommunale forvaltningsområder. Fagforvaltningschefer indgår derfor ikke i den øverste administrative ledelse. I stedet består denne af en række direktører uden dagligt driftsansvar for en forvaltning (Christensen et al., 2007: 62, 122; Jespersen, 2008: 104f). For at fremstå som en helhed er direktionens indstillinger til politikerne udtryk for direktionens samlede holdning (se Bækgaard et al., 2009: 225 for et eksempel). Serviceringen af fagudvalgene foretages i udgangspunktet også som udgangspunkt af direktionen” (Bækgaard 2013, 163).

Jeg har i et spørgeskema indsamlet en række oplysninger om den nuværende kommunale organisation, jævnfør det efterfølgende afsnit. Heri indgår - ud over driftsansvaret - spørgsmålet om, hvem der forelægger sager til politisk beslutning. Er det den samlede direktion eller en enkelt direktør? Spørgeskemaet blev udsendt i foråret 2014 og blev besvaret af 87 kommuner. Skemaet var stilet til kommunaldirektørerne, men blev i en række tilfælde besvaret af andre. Om svarene under alle omstændigheder er drøftet med kommunaldirektøren vides ikke. Svarene er derfor selvsagt præget af topledelsens synsvinkel. Spørgsmålene er dog søgt udformet, så der er så lille plads til et skønsmæssigt svar som muligt. Hertil kommer, at hensigten har været at belyse ikke mindst den øverste ledelses organisering, som også er de respondenter der har svaret. Det antages derfor, at svarene er valide.

I tabel 1 vises på grundlag af denne undersøgelse, hvilken rolle direktørerne har - forvaltningschef, referencedirektør eller direktører uden tilknytning til et bestemt område.

Tabel 1. Hvilken rolle har det enkelte medlem af direktionen, bortset fra kommunaldirektøren?

\begin{tabular}{|l|l|l|}
\hline & Respondenter & Procent \\
\hline Chef for en fagforvaltning eller tværgående forvaltning & 37 & 42,5 \\
\hline Chef for en fagforvaltning plus en tværgående forvaltning & 8 & 9,2 \\
\hline $\begin{array}{l}\text { Referencedirektør for et antal afdelinger/centre, som refererer til } \\
\text { direktionen }\end{array}$ & 41 & 47,1 \\
\hline Alene medlem af direktionen & 1 & 1,1 \\
\hline I alt & 87 & 100 \\
\hline
\end{tabular}

Tabel 2 viser tilsvarende, hvilken rolle kommunaldirektøren har. 
Tabel 2. Kommunaldirektørens rolle

\begin{tabular}{|l|l|l|}
\hline & Respondenter & Procent \\
\hline Forvaltningschef & 11 & 12,6 \\
\hline Referencedirektør for et antal afdelinger & 48 & 55,2 \\
\hline Alene øverste administrative chef & 28 & 32,2 \\
\hline I alt & 87 & 100 \\
\hline
\end{tabular}

Det fremgår, at omkring halvdelen af kommunerne har en traditionel forvaltningsstruktur, dog således at direktørerne i knap 10 procent af kommunerne også har ansvar for en tværgående afdeling. Godt en tiendedel af kommunaldirektørerne er også forvaltningschefer.

Kun én kommune angiver, at direktørernes eneste rolle er at være direktionsmedlemmer. Næsten halvdelen karakteriserer dem som referencedirektører. Det betyder, at kommunen principielt har en direktion, men at der samtidig er en arbejdsdeling direktørerne imellem. I praksis kan rollen som referencedirektør formentlig variere fra at ligne en forvaltningschef til at komme tæt på et generalistorienteret direktionsmedlem. Der kan derfor være grund til at belyse den mere præcise rolle lidt nærmere. Det sker gennem svarene på spørgsmålene om, hvem der har ansvaret for betjeningen af henholdsvis økonomiudvalg og fagudvalg.

Tabel 3. Hvem er ansvarlig for sagsforberedelsen i fagudvalg?

\begin{tabular}{|l|l|l|}
\hline & Respondenter & Procent \\
\hline Den samlede direktion med borgmesterens medvirken & 7 & 8 \\
\hline Den samlede direktion & 11 & 12,6 \\
\hline En af direktørerne & 58 & 66,7 \\
\hline En afdelingschef/centerchef & 11 & 12,6 \\
\hline I alt & 87 & 100 \\
\hline
\end{tabular}

I to tredjedele af alle kommuner er det en direktør, der har ansvaret for at forberede sager i fagudvalg. I kun cirka en femtedel af kommunerne ligger ansvaret i den samlede direktion. Sammenlignet med sagsforberedelsen til fagudvalgene er sagsforberedelsen til økonomiudvalget i højere grad et direktionsanliggende, jævnfør tabel 4. Heraf fremgår det, at i godt og vel en tredjedel af kommunerne er det direktionen, der - ofte med borgmestermedvirken - er ansvarlig for dagsordenen til 
Økonomiudvalget. I de øvrige kommuner ligger ansvaret hos kommunaldirektøren eller en anden chef, formentlig typisk en sekretariatschef eller lignende.

Tabel 4. Hvem er ansvarlig for sagsforberedelsen i økonomiudvalget?

\begin{tabular}{|l|l|l|}
\hline & Respondenter & Procent \\
\hline Den samlede direktion med borgmesterens medvirken & 18 & 20,7 \\
\hline Den samlede direktion & 13 & 14,9 \\
\hline Kommunaldirektøren & 47 & 54 \\
\hline En af de øvrige chefer & 9 & 10,3 \\
\hline I alt & 87 & 100 \\
\hline
\end{tabular}

I tabel 5 er der foretaget en krydstabulering af svaret vedrørende sagsforberedelsen i fagudvalg og svaret vedrørende sagsforberedelsen i økonomiudvalget.

Tabel 5. Sammenhængen mellem sagsforberedelsen i fagudvalg og økonomiudvalg. \% af total.

\begin{tabular}{|c|c|c|c|c|c|}
\hline & \multicolumn{5}{|c|}{ Økonomiudvalg } \\
\hline & $\begin{array}{l}\text { Den samlede } \\
\text { direktion med } \\
\text { borgmesterens } \\
\text { medvirken }\end{array}$ & $\begin{array}{l}\text { Den samlede } \\
\text { direktion }\end{array}$ & $\begin{array}{l}\text { Kommunal- } \\
\text { direktøren }\end{array}$ & $\begin{array}{l}\text { En af de øvri- } \\
\text { ge chefer }\end{array}$ & I alt \\
\hline \multicolumn{6}{|l|}{ Fagudvalg } \\
\hline $\begin{array}{l}\text { Den samlede direktion } \\
\text { med borgmesterens } \\
\text { medvirken }\end{array}$ & 5,8 & 0,0 & 2,3 & 0,0 & 8,1 \\
\hline Den samlede direktion & 4,6 & 5,8 & 2,3 & 0,0 & 12,6 \\
\hline En af direktørerne & 5,8 & 9,2 & 46,0 & 5,8 & 66,7 \\
\hline $\begin{array}{l}\text { En afdelings- } \\
\text { chef/centerchef }\end{array}$ & 4,6 & 0,0 & 3,5 & 4,6 & 12.6 \\
\hline I alt & 20,7 & 14,9 & 54,0 & 10,3 & 100,0 \\
\hline
\end{tabular}

Tabellen viser, at 50 procent af kommunerne fortsat har, hvad der må betegnes som en klassisk forvaltningsmodel. Det er en (fag)direktør/afdelingschef, der forbereder fagudvalgenes møder, mens kommunaldirektøren eller en af hans/hendes håndgangne mænd/kvinder forbereder møderne i økonomiudvalget. I godt 15 procent af kommunerne tager direktionen sig af indstillinger til økonomi- 
udvalget, mens en direktør står for indstillinger til fagudvalg. Det er naturligvis muligt, at de sidstnævnte indstillinger forinden er drøftet i direktionen. Hvis det er en anden chef, der indstiller til fagudvalg, men direktionen til økonomiudvalget, er der formentlig tale om, at den pågældende udfører, hvad direktionen har besluttet.

Alt i alt lever forvaltningsmodellen altså i bedste velgående. Lægger man vægt på det administrative ansvar har cirka halvdelen af kommunerne en forvaltningsmodel. Lægger man vægt på sagsforberedelsen i fagudvalg er det nærmere to tredjedele. Når det er sagt, er det værd at understrege, at udviklingen synes at være gået i retning af en stærkere tværgående koordinering. Således er kommunerne blevet spurgt om, hvordan strukturen var før den seneste organisationsændring. Af svarene (ikke vist her) fremgår det, at de ikke særligt talrige ændringer typisk går i retningen fra forvaltningsmodel til direktionsmodel.

\section{Samspillet med de decentrale institutioner}

Det har i mange år været god latin, at et klart decentralt ansvar fremmer den økonomiske ansvarlighed. Derfor har institutionslederne fået større råderum, herunder større mulighed for at overføre uforbrugte bevillinger fra år til år. I den teoretiske litteratur har meningerne været mere delte (Blom Hansen 2002, Dietrichson og Ellegård 2012). På den baggrund er det interessant at undersøge, i hvilket omfang de kommunale institutioner faktisk kan disponere, og hvilke styringselementer, der anvendes over for dem. Den følgende undersøgelse heraf omfatter blandt andet følgende elementer:

a) Anvendes der målstyring?

b) Fordelingen af budgettet - anvendes et taxametersystem eller anden fordeling efter en objektiv og produktionsrelateret nøgle?

c) Hvor meget råder institutionslederne over budgettet - er der tale om en samlet beløbsramme, som de kan disponere indenfor, eller er der i alt fald en adskillelse mellem lønmidler og andre midler?

d) Hvordan er mulighederne for at overføre bevillinger fra år til år?

\section{Ad a) Målstyring}

Der er stillet spørgsmål om, hvorvidt der i budgettet fastsættes mål for tre nærmere angivne områder. Resultaterne vises i tabel 6. 
Tabel 6. Mål for enkelte områder, \%

\begin{tabular}{|l|l|l|l|}
\hline & Skoleområdet & Daginstitutionsområdet & Ældreområdet \\
\hline $\begin{array}{l}\text { Nej, budgettet drejer sig } \\
\text { alene om bevillinger }\end{array}$ & 24,7 & 24,7 & 25,9 \\
\hline $\begin{array}{l}\text { Ja, men målene er udtrykt i } \\
\text { generelle vendinger }\end{array}$ & 47,1 & 51,8 & 49,4 \\
\hline $\begin{array}{l}\text { Ja, der fastsættes konkrete } \\
\text { mål }\end{array}$ & 28,2 & 23,5 & 24,7 \\
\hline I alt (N) & 85 & 85 & 85 \\
\hline
\end{tabular}

Man kunne måske have forventet, at der ville være forskel mellem områderne. Skoleområdet har været meget $\mathrm{i}$ fokus, og der er her gennemarbejdede tal for resultaterne, som let kan danne grundlag for opstilling af mål. Men der er en forbløffende ensartethed mellem de tre områder. Cirka halvdelen af kommunerne holder sig til at formulere mål i generelle vendinger, en fjerdedel opstiller slet ikke mål i budgettet (hvilket ikke behøver at betyde, at de ikke findes), og den sidste fjerdedel har konkrete mål.

Ad b) Hvordan fordeles budgettet mellem institutionerne og hvor stor råderet har lederen?

Det er et centralt element i forestillingerne om decentralisering, at den enkelte institutionsleder bør kunne forudse sit budget, skal kunne råde frit over budgettet og skal kunne bruge mindreforbrug $\mathrm{i}$ efterfølgende år. Lederen vil så have en stærk tilskyndelse til at drive institutionen med det mindst mulige ressourceforbrug. Det første element i decentraliseringen er klare regler for ressourcefordelingen. Resultaterne vises i tabel 7.

Tabel 7. Fordelingen af budgettet på forskellige områder i \%

\begin{tabular}{|l|l|l|l|}
\hline & Skoleområdet & Daginstitutionsområdet & Ældreområdet \\
\hline $\begin{array}{l}\text { Overvejende på grundlag } \\
\text { af et taxametersy- } \\
\text { stem/antal visiterede ydel- } \\
\text { ser eller klienter }\end{array}$ & 91,8 & 94,1 & 82,4 \\
\hline På anden måde & 8,2 & 5,9 & 17,6 \\
\hline I alt $(\mathrm{N})$ & 85 & 85 & 85 \\
\hline
\end{tabular}

Billedet er ganske entydigt: Langt de fleste kommuner fordeler bevillingerne efter en mere eller mindre objektiv nøgle. Det kan dog ikke udelukkes, at der ved siden af er puljer, som fordeles mere 
skønsmæssigt. Det ser også ud til, at lederne i betydelig grad har rådighed over, hvordan pengene bruges, hvilket fremgår af tabel 8. Ifølge denne tabel siger næsten ni ud af ti kommuner, at lederne har fuld rådighed over budgettet, og der gælder tilsyneladende ensartede regler på alle områder.

Tabel 8. Institutionsledernes rådighed over budgettet

\begin{tabular}{|l|l|l|l|}
\hline & Skoleområdet & Daginstitutionsområdet & Ældreområdet \\
\hline $\begin{array}{l}\text { Budgettet er en samlet beløbs- } \\
\text { ramme, som de har fuld rådig- } \\
\text { hed over }\end{array}$ & 87,1 & 87,1 & 87,1 \\
\hline $\begin{array}{l}\text { Budgettet er som minimum } \\
\text { fordelt på løn og drift }\end{array}$ & 12,9 & 12,9 & 12,9 \\
\hline I alt $(\mathrm{N})$ & 85 & 85 & 85 \\
\hline
\end{tabular}

Der er noget større forskelle mellem kommuner, hvad angår reglerne om overførsel af bevillinger fra år til år, men det dominerende billede er, at lederne kan regne med at kunne bruge et eventuelt mindreforbrug i de efterfølgende år. Dette fremgår af tabel 9. Man kan spørge, om svarene på dette punkt nu også står til troende. Vurderingen er, at det gør de, blandt andet fordi udformningen af spørgsmålet gav gode muligheder for et negativt svar, for eksempel begrundet med de aktuelle økonomiske udfordringer. Tabel 9 viser, at godt to tredjedele af alle kommuner siger, at der gælder regler, som ikke fraviges (det er ikke ensbetydende med, at alle mindreudgifter kan overføres, men incitamentsvirkningen i forhold til lederne er klar). Kun ganske få har ikke overførselsadgang.

Tabel 9. Overførselsadgang

\begin{tabular}{|l|l|l|}
\hline $\begin{array}{l}\text { Der gælder regler om automatisk overførselsadgang, som } \\
\text { aldrig fraviges }\end{array}$ & Respondenter & Procent \\
\hline $\begin{array}{l}\text { Der gælder regler om automatisk overførselsadgang, som } \\
\text { dog er fraveget i 12 eller 13, fordi det samlede budget var i } \\
\text { fare for at blive overskredet }\end{array}$ & 97,1 \\
\hline Overførselsadgangen besluttes konkret hvert år & 17 & 10,6 \\
\hline $\begin{array}{l}\text { Der er ikke adgang til overførsel af mer- eller mindreforbrug } \\
\text { fra år til år }\end{array}$ & 2 & 20 \\
\hline I alt & 85 & 2,4 \\
\hline
\end{tabular}

Sammenfattende ser det ud til, at der, hvad angår decentralisering, er en betydelig større ensartethed kommunerne imellem, end hvad angår den øverste ledelses udformning. Institutionslederne kan 
disponere over budgettet og kan i de fleste kommuner regne med at kunne bruge mindreforbrug $\mathrm{i}$ efterfølgende år. Dog tegner svarene vedrørende målstyring et mere kompliceret billede, idet kun en fjerdedel har præcise mål, så budgettet - i alt fald i princippet - drejer sig om både, hvad der skal nås, og hvad det må koste.

\section{Gør organisation en forskel? Teoretiske overvejelser. Hidtidige resultater}

Der er en vis forskel mellem praktikeres og mange teoretikeres opfattelse af virkningen af organisationsændringer. I forvaltningen er organisationsændringer et af de hyppigst anvendte midler til realisering af overordnede politisk/administrative mål. I den teoretiske litteratur er der derimod nogen skepsis. Nogle forfattere mener, at praktikerne har ret. Således har Thomas Hammond (Hammond 1986; Hammond og Knott 1996) gennem en opstilling af en række matematiske modeller vist, at forskellige organisationsstrukturer kan have væsentlig betydning for, hvilke beslutninger der træffes i organisationen. Det betyder, at reorganiseringer antages at virke og dermed kan bruges som instrument.

Den sociologiske institutionalisme har et andet syn på sagen. Ifølge en indflydelsesrig fremstilling (March og Olsen 2006) er organisationer langt hen ad vejen drevet af normer for, hvad der anses for passende i organisationen, ritualer og gentagne handlemønstre. Reformer som for eksempel reorganiseringer er derfor et resultat af tilpasning til omgivelsernes krav. De gennemføres for at bevare organisationens legitimitet, ikke for at opnå et bestemt resultat. Bækgaard et al. (2009) fremhæver, at dette ikke er ensbetydende med, at de ikke har noget formål. Bækgaard et al. (2009) sondrer således mellem konceptformålet - det officielle mål - og sideformålet. En direktionsmodel kan for eksempel indføres med det formål at nedbringe sektoriseringen - konceptformålet. Men et sideformål kan være at få flyttet en chef.

En kritik mod den sociologiske institutionalisme er, at den har svært ved at forklare og forstå forandring. Denne kritik afbødes i nogen grad i den videreudvikling af teorien, der kaldes perspektivet om institutionelle logikker (Ryom Villadsen 2013). Institutionelle logikker defineres som "den konfiguration af institutioner, der er dominerende i et givet rum og tid, og som giver mening til individer og deres hverdag" (Ryom Villadsen 2013, 121). Da sådanne logikker kan udskiftes, er der mulighed for forandring. Med afsæt i denne tankegang viser Ryom Villadsen (2013), at kommunale organisationsændringer kan beskrives som en diffusionsproces, hvor kommunerne i høj grad lader sig påvirke af, hvad andre gør - og dermed af, hvad der er oppe i tiden. 
Det interessante ved tankegangen om institutionelle logikker er, at den ser organisationsændringer som i høj grad bestemt af omgivelserne samtidig med, at den ikke udelukker, at de kan forfølge et veldefineret formål. En ny institutionel logik kunne jo have en rationel begrundelse.

Organiseringen af den øverste administrative ledelse i kommunerne forekommer at være velegnet som genstandsfelt for, hvilken af de tre skitserede tilgange - den rationelle, den sociologiskinstitutionelle og den institutionelle logik - der bedst forklarer de ændringer, der er sket. Der har utvivlsomt været tale om en fælles bevægelse i mange kommuner. Spørgsmålet er da, om der blot har været tale om en mode, eller om der er mening med galskaben?

Begrundelsen for at vælge en direktionsmodel frem for en forvaltningsmodel er som nævnt typisk, at en direktion angiveligt modvirker en sektortankegang og sikrer en bedre koordination på tværs. Med Bækgaards formulering: "Eftersom direktionsmedlemmerne ikke har en organisatorisk tilknytning til en bestemt forvaltning, antages den administrative ledelse i højere grad at agere som udgiftsvogtere i kommuner med direktionsmodeller end i kommuner med forvaltningsmodeller" (Bækgaard 2013, 163). Med andre ord er hypotesen, at de styrbare udgifter vokser langsommere, hvis kommunen har en direktionsmodel. Samme logik fører til en forventning om, at det skattefinansierede driftsresultat bliver større med en direktionsmodel.

Flere aspekter af denne problemstilling er tidligere belyst. Martin Bækgaard (Bækgaard 2010) har undersøgt, hvordan anvendelse af ledelsesmodeller påvirker dels oplevelsen af sektorisering, dels interaktionsmønstret mellem politikere og embedsmænd. Hans konklusion er, at der ikke er nogen sammenhæng mellem anvendelse af bestemte organisationsmodeller og politikernes grad af oplevet sektorisering. Derimod påvirkes interaktionsmønstret, idet direktørerne har mindre kontakt med fagudvalgspolitikerne og mere med borgmesteren. Det er en rimelig formodning, at dette også fører til en svækkelse af fagudvalgenes indflydelse og til en styrkelse af borgmesteren. Og måske fører det også til en styrkelse af administrationen. Bækgaard (2013) har i alt fald konkluderet, "at politikernes udgiftspræferencer ikke har indflydelse på ændringerne i kommunernes regnskabsmæssige resultater i kommuner, der anvender direktionsmodeller, men til gengæld en markant effekt $\mathrm{i}$ kommuner, der anvender forvaltningsmodeller” (Bækgaard 2013, 159). Bækgaard har også vist, at der er en signifikant sammenhæng mellem den oplevede sektorisering og antallet af fagudvalg/fagforvaltninger (Bækgaard 2010).

Disse resultater giver grundlag for at formode, at hensynet til økonomistyringen vil veje tungere, når der er en direktionsmodel, og at dette også vil føre til, at det skattefinansierede driftsresultat bliver større. 


\section{Gør organisation en forskel? Empiri}

\section{Hypotese og variable}

Undersøgelsen af betydningen af den administrative organisation er gennemført som en del af et Ph.d-projekt om økonomistyring i danske kommuner efter den seneste kommunalreform. I undersøgelsen anvendes flere forskellige mål for økonomistyring. Her er alene gengivet resultaterne vedrørende det skattefinansierede driftsresultat. Denne størrelse er hyppigt anvendt i litteraturen. Hansen et al. (2014) fremhæver, at driftsresultatet er den vigtigste dimension i økonomistyringen, fordi den afspejler den langsigtede balance i kommunen og muligheden for at finansiere anlæg og evnen til at håndtere økonomiske udfordringer, eksempelvis et udgiftspres eller lavere indtægter. Den hypotese, der skal undersøges, er altså:

Det skattefinansierede driftsresultat vil voere større, hvis der anvendes en direktionsmodel, end hvis der anvendes en forvaltningsmodel.

Det empiriske grundlag for at teste denne hypotese er de danske kommunale regnskaber for perioden 2011-2013. I hele denne periode var der en relativt stram statslig regulering af den kommunale budgetlægning. Der var således både loft over skatter og serviceudgifter, og der var hjemmel til at sanktionere rammeoverskridelser. Dette blev dog ikke aktuelt, da kommunerne i hvert af årene overholdt den økonomiaftale, som regeringen og Kommunernes Landsforening havde indgået. Hypoteserne undersøges ved at opstille og analysere en række modeller til forklaring af det skattefinansierede driftsresultat. I modellerne indgår flere typer af forklarende variable, der præsenteres herunder (se i øvrigt bilag 1 for definition, kilde og beskrivende statistik):
a) Økonomiske variable og andre baggrundsvariable (omgivelsesvariable)
b) Den politiske struktur
c) Administrativ organisation, direktion
d) Andre administrative variable
e) Årsdummyer, der bl.a. kan opfattes som et mål for virkningen af den statslige regulering

\section{Ad a) Økonomiske og andre baggrundsvariable}

Det er velkendt, at de økonomiske vilkår har stor betydning for økonomistyringen (Mouritzen 1990, Houlberg og Kræn Jensen 2010). Her er valgt fire variable. 
- Udgiftspres, defineret som udgiftsbehov per indbygger $\mathrm{i}$ danske kroner divideret med indtægter fra skatter og tilskud i danske kroner per indbygger. Formodningen er, at jo større udgiftsbehovet er i forhold til indtægterne, des mindre vil overskuddet alt andet lige være (variabelnavn: Udgiftspres).

- Endringer af indtægter per indbygger i danske kroner, defineret som ændring i forhold til året før. Stigninger i indtægterne, især hvis de er uforudsete, vil formentlig i første omgang føre til et større overskud (variabelnavn: Indt.cendr.).

- Indbyggertal, idet det formodes at større kommuner vil have større kapacitet til at styre udgifterne. Sammenhængen er dog næppe lineær, så den naturlige logaritme er brugt som variabel (variabelnavn: Lnindb.).

- Likviditet året før per indbygger i danske kroner, idet behovet for et driftsoverskud til finansiering af anlæg med videre er mindre, jo større likviditeten er (variabelnavn: Likv. året før.).

\section{Ad b) Politisk struktur}

Det er et centralt tema $\mathrm{i}$ en stor del af litteraturen om økonomistyring, at resultaterne bliver bedre, hvis processen er centralt ledet. For så vidt angår den politiske struktur, arbejdes der her med et enkelt mål for, i hvilken grad magten er samlet. Det er borgmesterens partis mandatandel (som andel fra 0 til 1, variabelnavn: Borgm.andel). Formodningen er, at des stærkere borgmesteren står, des større vil det skattefinansierede driftsresultat være, jævnfør Borge (2004).

\section{Ad c) Administrativ organisation (direktionsmodel)}

På grundlag af de refererede svar fra surveyen, er der konstrueret fire modeller for kommunernes administrative organisering, der vises i tabel 10. På baggrund af denne opdeling er der herefter konstrueret en dummy, hvor ren og modificeret forvaltningsmodel er kodet 0 , mens ren og modificeret direktionsmodel er kodet 1 (variabelnavn: Direktion (dummy)). 
Tabel 10. Fire modeller for den øverste administrative ledelse

\begin{tabular}{|c|c|c|c|c|}
\hline & $\begin{array}{l}\text { Direktør } \\
\text { Rolle }\end{array}$ & $\mathrm{KD}$ rolle & $\begin{array}{l}\text { Forelæggelse af } \\
\text { sager for fagudvalg }\end{array}$ & $\begin{array}{l}\text { Procent } \\
\text { af total }\end{array}$ \\
\hline $\begin{array}{l}\text { 1. Ren } \\
\text { forvaltningsmodel }\end{array}$ & $\begin{array}{l}\text { Chef for en fag- } \\
\text { forvalt. og/eller } \\
\text { tværg. forv. }\end{array}$ & $\begin{array}{l}\text { Chef for en } \\
\text { forv. }\end{array}$ & - & 12,9 \\
\hline $\begin{array}{l}\text { 2. Modificeret } \\
\text { forvaltningsmodel }\end{array}$ & $\begin{array}{l}\text { Chef for en fag- } \\
\text { forvalt. og/eller } \\
\text { tværg. forv }\end{array}$ & $\begin{array}{l}\text { Reference } \\
\text { direktør eller } \\
\text { alene } \\
\text { øverste adm. } \\
\text { chef }\end{array}$ & - & 36,9 \\
\hline $\begin{array}{l}\text { 3.Modificeret } \\
\text { direktionsmodel }\end{array}$ & $\begin{array}{l}\text { Reference } \\
\text { direktør eller } \\
\text { alene medlem af } \\
\text { direktionen }\end{array}$ & - & $\begin{array}{l}\text { En direktør er } \\
\text { ansvarlig }\end{array}$ & 31,8 \\
\hline \multirow[t]{2}{*}{ 4. Ren direktionsmodel } & $\begin{array}{l}\text { Reference } \\
\text { direktør eller } \\
\text { alene medlem af } \\
\text { direktionen }\end{array}$ & - & $\begin{array}{l}\text { Direktionen eller } \\
\text { en afd.chef er } \\
\text { ansvarlig }\end{array}$ & 18,4 \\
\hline & & & & 100,0 \\
\hline
\end{tabular}

Ad d) Andre organisatoriske variable (alle dummyer)

- Har kommunen en økonomisk målsætning? (1: Konkrete definerede, 0: ingen mål eller ikke kvantificerede mål) (variabelnavn: Øk.mål (dummy)).

- Har kommunen en økonomisk ramme for såvel de samlede udgifter som for det enkelte udvalgs udgifter (1: Ramme for både det samlede budget og de enkelte områder, 0: Ingen ramme eller kun samlet ramme) (variabelnavn: Ramme (dummy)).

- Decentralisering, målt ved adgangen til at videreføre bevillinger (1: Der er regler for overførsel af bevillinger som aldrig fraviges, 0: Andre svar) (variabelnavn: Decentr. (dummy)).

- Målstyring på institutioner (1: Der er opstillet konkrete mål i budgettet, 0: Ingen mål eller generelt formulerede mål) (variabelnavn: Målstyring (dummy)).

Ad e) Årsdummyer

Indgår som mål for blandt andet virkningen af de årlige kommuneaftaler. 


\section{Data}

Data til at måle de beskrevne variable er hentet fra to typer kilder. De økonomiske baggrundsvariable er hentet fra officielle kilder og foreligger derfor for alle kommuner. De øvrige variable er hentet fra spørgeskemaundersøgelsen (se bilag 1).

\section{Analyser}

Der er opstillet tre modeller, der estimeres med henholdsvis OLS og "random effects" (RE), og både det budgetterede og det realiserede driftsresultat analyseres. Begrundelsen for at analysere både det budgetterede og det realiserede resultat er, at det budgetterede resultat er et direkte resultat af politiske beslutninger, mens det realiserede også beror på udefrakommende ændringer.

Model 1/1a ser på sammenhængen mellem eksistensen af en direktionsmodel og det skattefinansierede driftsresultat, når der kontrolleres for økonomiske variable og andre baggrundsvariable (omgivelsesvariable), den politiske struktur og årsdummies. Foruden variablene fra model 1/1a, medtager model 2/2a indikatorer for effekten af den centrale styring, det vil sige om der findes konkrete økonomiske målsætninger, og om kommunen har en økonomisk ramme for såvel de samlede udgifter som for det enkelte udvalgs udgifter. Endelig medtager model 3/3a, foruden de samme variable som i model 1/1a, indikatorer for decentralisering $\mathrm{i}$ form af adgangen til at videreføre bevillinger, og om kommunen opstiller konkrete mål for de decentrale institutioner i budgettet. Tabel 11 viser resultaterne vedrørende det budgetterede skattefinansierede driftsresultat.

Det fremgår, at omgivelsesvariable (økonomiske variable og andre baggrundsvariable) og årsdummyer udviser en signifikant sammenhæng med det skattefinansierede driftsresultat. Eksistensen af en direktion er også signifikant med positivt fortegn i alle tre modeller og uanset om estimationsmetoden er OLS eller RE. Om man har målstyring, rammestyring, målstyring og decentralisering synes derimod ikke at gøre den store forskel.

Tabel 12 viser tilsvarende resultaterne for så vidt angår det realiserede skattefinansierede driftsresultat. 
Tabel 11. Administrativ struktur og budgetteret skattefinansieret driftsresultat 2011-13

\begin{tabular}{|c|c|c|c|c|c|c|}
\hline Model & Model 1 & Model 1a & Model 2 & Model 2a & Model 3 & Model 3a \\
\hline Estimation & OLS & $\mathrm{RE}$ & OLS & $\mathrm{RE}$ & OLS & RE \\
\hline \multicolumn{7}{|c|}{ Økonomiske variable og andre baggrundsvariable } \\
\hline \multirow[t]{2}{*}{ Udgiftspres } & $-8,408 * * *$ & $-12,579 * * *$ & $-8,644 * * *$ & $-12,755 * * *$ & $-7,912 * * *$ & $-12,247 * * *$ \\
\hline & $(-2,346)$ & $(-2,218)$ & $(-2,337)$ & $(-2,238)$ & $(-2,308)$ & $(-2,243)$ \\
\hline \multirow[t]{2}{*}{ Indt.ændr. } & $0.244 * * *$ & $0.255^{* * *}$ & $0.237 * * *$ & $0.252 * * *$ & $0.242 * * *$ & $0.256^{* * *}$ \\
\hline & $(0.0624)$ & $(0.0387)$ & $(0.0624)$ & $(0.0388)$ & $(0.0634)$ & $(0.0388)$ \\
\hline \multirow[t]{2}{*}{ Lnindb } & $396.0 * * *$ & $516.4 * * *$ & $372.7 * * *$ & $494.8 * * *$ & $348.7 * *$ & $480.3 * * *$ \\
\hline & $(132.1)$ & $(131.2)$ & $(131.2)$ & $(133.0)$ & $(133.0)$ & $(136.9)$ \\
\hline \multirow[t]{2}{*}{ Likv. året før } & $0.0794 *$ & 0.0130 & $0.0819^{*}$ & 0.0139 & $0.0785^{*}$ & 0.0128 \\
\hline & $(0.0440)$ & $(0.0279)$ & $(0.0446)$ & $(0.0282)$ & $(0.0422)$ & $(0.0280)$ \\
\hline \multicolumn{7}{|l|}{ Den politiske struktur } \\
\hline \multirow[t]{2}{*}{ Borgm.andel } & 672.1 & 850.2 & 746.6 & 917.9 & 515.7 & 727.6 \\
\hline & $(493.9)$ & (728.7) & $(491.5)$ & (733.3) & $(482.9)$ & $(740.1)$ \\
\hline \multicolumn{7}{|c|}{ Den administrative organisation } \\
\hline \multirow[t]{2}{*}{ Direktion (dummy) } & $428.7 * *$ & $348.5^{*}$ & $455.2 * * *$ & $372.5 * *$ & $444.2 * * *$ & $361.2 * *$ \\
\hline & $(164.8)$ & $(181.7)$ & $(163.4)$ & $(183.3)$ & $(167.4)$ & $(182.1)$ \\
\hline \multicolumn{7}{|c|}{ Andre administrative variable } \\
\hline \multirow[t]{2}{*}{ Øk.mål (dummy) } & & & 78.12 & 48.77 & & \\
\hline & & & $(203.4)$ & $(214.6)$ & & \\
\hline \multirow[t]{2}{*}{ Ramme (dummy) } & & & 191.2 & 195.4 & & \\
\hline & & & $(157.3)$ & $(192.0)$ & & \\
\hline \multirow[t]{2}{*}{ Decentr. (dummy) } & & & & & -43.35 & -44.84 \\
\hline & & & & & $(156.2)$ & (197.6) \\
\hline \multirow[t]{2}{*}{ Målstyring (dummy) } & & & & & 268.8 & 216.4 \\
\hline & & & & & $(209.3)$ & (218.6) \\
\hline \multicolumn{7}{|c|}{ Årsdummies (reference = 2011) } \\
\hline \multirow[t]{2}{*}{ Dummy2012 } & $-780.6^{* * *}$ & $-793.3 * * *$ & $-771.6^{* * *}$ & $-791.9 * * *$ & $-771.2 * * *$ & $-792.3 * * *$ \\
\hline & (126.7) & (111.1) & $(127.4)$ & (111.4) & $(125.4)$ & (111.4) \\
\hline \multirow[t]{3}{*}{ Dummy2013 } & $-501.4 * * *$ & $-529.3 * * *$ & $-508.1 * * *$ & $-534.5 * * *$ & $-484.0 * * *$ & $-519.7 * * *$ \\
\hline & $(121.6)$ & $(110.6)$ & (121.8) & (111.6) & $(118.1)$ & (111.3) \\
\hline & & & & & $(209.3)$ & $(218.6)$ \\
\hline \multirow[t]{2}{*}{ Konstant } & $5,135^{* *}$ & $8,289 * * *$ & $5,424 * *$ & $8,525 * * *$ & $5,146 * *$ & $8,347 * * *$ \\
\hline & $-2,212$ & $-2,192$ & $-2,225$ & $-2,211$ & $-2,263$ & $-2,194$ \\
\hline $\mathrm{N}$ & 255 & 255 & 255 & 255 & 255 & 255 \\
\hline $\mathrm{r} 2$ & 0.257 & & 0.267 & & 0.269 & \\
\hline
\end{tabular}

$* * * \mathrm{p}<0.01, * * \mathrm{p}<0.05, * \mathrm{p}<0.1$. OLS med klyngekorrigerede standardfejl. 
Tabel 12. Administrativ struktur og realiseret skattefinansieret driftsresultat 2011-13

\begin{tabular}{|c|c|c|c|c|c|c|}
\hline Model & Model 1 & Model 1a & Model 2 & Model 2a & Model 3 & Model 3a \\
\hline Estimation & OLS & $\mathrm{RE}$ & OLS & $\mathrm{RE}$ & OLS & $\mathrm{RE}$ \\
\hline \multicolumn{7}{|c|}{ Økonomiske variable og andre baggrundsvariable } \\
\hline \multirow[t]{2}{*}{ Udgiftspres } & $-9,601 * * *$ & $-13,108 * * *$ & $-9,784 * * *$ & $-13,275^{* * *}$ & $-9,012 * * *$ & $-12,523 * * *$ \\
\hline & $(-2,317)$ & $(-2,601)$ & $(-2,32)$ & $(-2,644)$ & $(-2,287)$ & $(-2,602)$ \\
\hline \multirow[t]{2}{*}{ Indt.ændr } & $0.404 * * *$ & $0.385 * * *$ & $0.402 * * *$ & $0.384 * * *$ & $0.403 * * *$ & $0.388 * * *$ \\
\hline & $(0.0606)$ & $(0.0537)$ & $(0.0610)$ & $(0.0538)$ & $(0.0608)$ & $(0.0537)$ \\
\hline \multirow[t]{2}{*}{ Lnindb } & $283.6^{*}$ & $388.8 * * *$ & $270.2^{*}$ & $380.5^{* *}$ & 219.7 & $329.1 * *$ \\
\hline & $(159.8)$ & $(146.0)$ & $(155.6)$ & $(149.3)$ & $(147.8)$ & $(150.5)$ \\
\hline \multirow[t]{2}{*}{ Likv året før } & $0.138^{* * *}$ & 0.0526 & $0.142 * * *$ & 0.0519 & $0.137 * * *$ & 0.0537 \\
\hline & $(0.0453)$ & $(0.0349)$ & $(0.0463)$ & $(0.0355)$ & $(0.0431)$ & $(0.0346)$ \\
\hline \multicolumn{7}{|l|}{ Den politiske struktur } \\
\hline \multirow[t]{2}{*}{ Borgm.andel } & 500.8 & 657.5 & 547.7 & 693.3 & 311.4 & 485.6 \\
\hline & $(626.6)$ & $(801.8)$ & $(619.6)$ & $(814.2)$ & $(581.1)$ & $(802.6)$ \\
\hline \multicolumn{7}{|c|}{ Den administrative organisation } \\
\hline \multirow[t]{2}{*}{ Direktion (dummy) } & 313.6 & 204.7 & $325.6^{*}$ & 214.2 & $322.2^{*}$ & 215.1 \\
\hline & $(191.6)$ & $(203.1)$ & $(195.4)$ & $(206.7)$ & $(190.0)$ & $(200.7)$ \\
\hline \multicolumn{7}{|c|}{ Andre administrative variable } \\
\hline \multirow[t]{2}{*}{ Øk. måls. (dummy) } & & & 89.72 & 28.08 & & \\
\hline & & & $(212.6)$ & $(239.0)$ & & \\
\hline \multirow[t]{2}{*}{ Ramme (dummy) } & & & 80.70 & 91.24 & & \\
\hline & & & $(185.9)$ & $(213.2)$ & & \\
\hline \multirow[t]{2}{*}{ Decentr. (dummy) } & & & & & $355.6^{*}$ & $357.4 *$ \\
\hline & & & & & $(193.0)$ & (214.3) \\
\hline \multirow[t]{2}{*}{ Målstyring (dummy) } & & & & & 241.0 & 206.5 \\
\hline & & & & & $(208.6)$ & (237.6) \\
\hline \multicolumn{7}{|c|}{ Årsdummies (reference = 2011) } \\
\hline \multirow[t]{2}{*}{ Dummy2012 } & $-284.3^{* *}$ & -200.1 & $-285.2^{* *}$ & -198.4 & $-285.1 * *$ & $-204.3^{*}$ \\
\hline & $(115.9)$ & $(123.8)$ & $(115.5)$ & $(124.0)$ & $(117.0)$ & $(124.0)$ \\
\hline \multirow[t]{2}{*}{ Dummy2013 } & 227.5 & $320.7 * *$ & 220.7 & $319.9 * *$ & 234.2 & $325.3 * *$ \\
\hline & $(149.4)$ & $(133.1)$ & $(149.5)$ & $(133.8)$ & $(149.8)$ & $(133.2)$ \\
\hline \multirow[t]{2}{*}{ Konstant } & $7,752 * * *$ & $10,465^{* * *}$ & $7,939 * * *$ & $10,641 * * *$ & $7,616^{* * *}$ & $10,274 * * *$ \\
\hline & $(-2,72)$ & $(-2,491)$ & $(-2,701)$ & $(-2,534)$ & $(-2,597)$ & $(-2,459)$ \\
\hline $\mathrm{N}$ & 255 & 255 & 255 & 255 & 255 & 255 \\
\hline $\mathrm{r} 2$ & 0.310 & & 0.312 & & 0.334 & \\
\hline
\end{tabular}

${ }^{* * *} \mathrm{p}<0.01,{ }^{* *} \mathrm{p}<0.05,{ }^{*} \mathrm{p}<0.1$. OLS med klyngekorrigerede standardfej1 
Igen er omgivelsesvariablerne signifikante, endda med større koefficientværdier end for det budgetterede driftsresultat. Derimod er koefficienterne for variablen "direktion" lidt mindre og kun signifikante i to af modellerne og kun i OLS-varianterne. Derudover er der en signifikant positiv sammenhæng, hvad angår decentralisering. Dette indikerer, at såfremt institutionerne har lov til at videreføre bevillinger, bliver overskuddet større - en effekt der ikke sås i det budgetterede overskud. I beregninger, der ikke er vist her, er der da også en klar sammenhæng mellem decentralisering og budgetoverholdelse. Derimod har anvendelsen af et rammesystem eller målstyring tilsyneladende ikke nogen signifikant effekt.

Konklusionen fra tabel 11 og 12 synes at være en forsigtig bekræftelse af hypotesen: Det gør en forskel, om man har en direktionsmodel frem for en forvaltningsmodel og effekten er i den forventede retning, således at eksistensen af en direktionsmodel giver signifikant større skattefinansierede driftsresultater.

Analyserne i tabel 11 og $12 \mathrm{er}$ - for at begrænse det samlede antal variable - gennemført med en forenklet opdeling i direktionsmodel/ikke direktionsmodel. Det indsamlede data muliggør som ovenfor nævnt imidlertid en opdeling i fire typer administrativ organisation. Med henblik på en dybere forståelse af mekanismen er der derfor gennemført en supplerende analyse af model 1 og 1a, hvor der i stedet for dummyen for direktion er anvendt tre dummyer, mens den rene forvaltningsmodel er referencekategori. De tre dummyer er modificeret forvaltningsmodel, modificeret direktionsmodel og ren direktionsmodel (se tabel 10).

Der er flere interessante resultater. Således er koefficienterne positive for alle direktionsdummyer i alle modeller, og bortset fra en enkelt af modellerne (model 3) er effekten større, så at sige jo mere direktion, der er. Den modificerede direktionsmodel har en større effekt end den modificerede forvaltningsmodel, og den rene direktionsmodel har en endnu større effekt. Ikke alle sammenhængene er dog signifikante. Begge direktionsmodeller (både den rene og den modificerede) har en signifikant sammenhæng med det budgetterede resultat, men kun for den modificerede direktionsmodel, og kun estimeret med OLS, gør det samme sig gældende for det realiserede resultat.

Hertil kommer, at effekten synes at være ganske betydelig: Har man eksempelvis en modificeret direktion, er det skattefinansierede driftsresultat omtrent 600 kroner per indbygger større end hvis man har en ren forvaltningsmodel uanset om man ser på det budgetterede eller realiserede driftsresultat (gælder dog ikke model 4, hvor effekten er lidt under 400 kroner per indbygger). De 600 kroner per indbygger svarer til en tredjedel af det budgetterede og en fjerdedel af det realiserede driftsresultat. 
Tabel 13. Administrativ struktur og driftsresultat. Fire administrative modeller.

\begin{tabular}{|c|c|c|c|c|}
\hline Model & $\begin{array}{l}\text { Model } 1 \text { - Budgetteret } \\
\text { driftsres. }\end{array}$ & $\begin{array}{l}\text { Model 2 - Budgetteret } \\
\text { driftsres. }\end{array}$ & $\begin{array}{l}\text { Model } 3 \text { - Realiseret } \\
\text { driftsres. }\end{array}$ & $\begin{array}{l}\text { Model } 4 \text { - Realiseret } \\
\text { driftsres. }\end{array}$ \\
\hline Estimation & OLS & $\mathrm{RE}$ & OLS & $\mathrm{RE}$ \\
\hline \multicolumn{5}{|c|}{$\begin{array}{l}\text { Økonomiske variable og andre baggrundsva- } \\
\text { riable }\end{array}$} \\
\hline \multirow[t]{2}{*}{ Udgiftspres } & $-8,948 * * *$ & $-13,103^{* * *} \quad-10,406^{* * *}$ & $-10,406 * * *$ & $-13,492^{* * *}$ \\
\hline & $(-2,55)$ & $(-2,292)$ & $(-2,253)$ & $(-2,707)$ \\
\hline \multirow[t]{2}{*}{ Indtændr } & $0.239^{* * *}$ & $0.251^{* * *}$ & $0.397^{* * *}$ & $0.383^{* * *}$ \\
\hline & $(0.0644)$ & $(0.0390)$ & $(0.0631)$ & $(0.0541)$ \\
\hline \multirow[t]{2}{*}{ Lnindb } & $447.0^{* * *}$ & $560.5^{* * *}$ & $335.7 * *$ & $423.4^{* * *}$ \\
\hline & $(122.1)$ & $(137.8)$ & $(166.7)$ & $(154.3)$ \\
\hline \multirow[t]{2}{*}{ Likv. året før } & $0.0991 * *$ & 0.0228 & $0.156^{* * *}$ & $0.0627^{*}$ \\
\hline & $(0.0392)$ & $(0.0291)$ & $(0.0428)$ & $(0.0368)$ \\
\hline \multicolumn{5}{|c|}{ Den politiske struktur } \\
\hline \multirow[t]{2}{*}{ Borgm.andel } & 475.0 & 783.3 & 474.2 & 553.5 \\
\hline & (494.5) & (735.3) & $(624.2)$ & $(817.7)$ \\
\hline \multirow{2}{*}{\multicolumn{5}{|c|}{ Den administrative organisation(reference $=$}} \\
\hline & & & & \\
\hline \multirow{2}{*}{ Mod.forv. (dummy) } & 406.1 & 341.2 & 408.5 & 266.0 \\
\hline & (339.6) & $(332.3)$ & $(375.0)$ & $(373.8)$ \\
\hline \multirow[t]{2}{*}{ Mod.dir. (dummy) } & $663.0^{*}$ & $598.5^{*}$ & $643.8^{*}$ & 372.0 \\
\hline & $(354.1)$ & $(323.3)$ & $(364.2)$ & $(365.5)$ \\
\hline \multirow[t]{2}{*}{ Ren dir. (dummy) } & $897.6^{* *}$ & $658.5^{*}$ & 625.0 & 492.3 \\
\hline & $(390.7)$ & $(343.8)$ & (466.4) & $(390.8)$ \\
\hline \multicolumn{5}{|c|}{ Årsdummies $($ reference $=2011)$} \\
\hline \multirow[t]{2}{*}{ Dumm2012 } & $-798.8^{* * *}$ & $-802.4^{* * *}$ & $-290.9^{* *}$ & $-209.4^{*}$ \\
\hline & (129.5) & (112.0) & (120.2) & (124.9) \\
\hline \multirow[t]{2}{*}{ Dummy2013 } & $-560.7^{* * *}$ & $-562.9^{* * *}$ & 190.1 & $292.8^{* *}$ \\
\hline & (131.1) & (115.5) & $(165.8)$ & (137.3) \\
\hline \multirow[t]{2}{*}{ Konstant } & $4,836^{* *}$ & $8,080^{* * *}$ & $7,636^{* * *}$ & $10,281^{* * *}$ \\
\hline & $-2,031$ & $-2,187$ & $-2,579$ & $-2,497$ \\
\hline $\mathrm{N}$ & 255 & 255 & 255 & 255 \\
\hline R2 & 0.273 & & 0.317 & \\
\hline
\end{tabular}

$* * * \mathrm{p}<0.01, * * \mathrm{p}<0.05, * \mathrm{p}<0.1$. OLS med klyngekorrigerede standardfejl 


\section{Konklusion og diskussion. Kommunalreformen og den administrative organisation}

Denne artikel har haft et tredobbelt sigte: 1) at beskrive udviklingen af den administrative organisation i kommunerne samt særligt, hvordan den er organiseret og virker efter kommunalreformen; 2) at bidrage til den teoretiske diskussion af virkninger af organisationsændringer; og 3) at diskutere i hvilket omfang ændringerne kan siges at være en følge af kommunalreformen.

Udviklingen siden 1970 kan opdeles i to faser. Lige efter den første kommunalreform blev der i langt de fleste kommuner etableret forvaltninger, knyttet til de enkelte udvalg. Forvaltningerne var ret selvstændige og den tværgående koordinering var svag. Frem til omkring årtusindskiftet skete der en konsolidering, så der blev færre forvaltninger, ligesom den administrative organisation blev løsrevet fra den politiske og koordineringen blev styrket. I tiden fra lige før den anden kommunalreform til i dag har ændringerne været koncentreret om dels den øverste ledelse (forvaltningsmodel eller direktionsmodel), dels om decentralisering.

Hvad angår organisationen i dag, kan der drages to konklusioner. Den ene er, at der fortsat er en betydelig variation. Det kan godt være, at den dominerende betegnelse for kommunernes øverste ledelsesforum i stigende grad er blevet "direktion". Men i mange kommuner lever forvaltningsmodellen i bedste velgående. Den anden er, at der er en betydelig decentralisering, hvis forandring over tid dog ikke er belyst.

Det næste spørgsmål er, om disse organisationsændringer har haft en effekt og om effekten svarer til hensigten. Direktionsmodellen ser i alt fald ud til at have virket som tænkt. Der er en positiv sammenhæng mellem at have en direktion og det skattefinansierede driftsresultat, $i$ alt fald i perioden 2011-2013. Umiddelbart bekræfter dette praktikernes og de rationelt orienterede teoretikeres opfattelse: Organisation betyder noget og organisationsændringer kan faktisk bruges som instrument.

Inden man drager denne konklusion alt for vidt, bør man imidlertid overveje, om udviklingen frem mod dagens kommunale forvaltningsopbygning har noget at gøre med kommunalreformen, hvilket jo også var artiklens udgangspunkt. Med det forbehold, at der under ingen omstændigheder kan gives et helt entydigt svar, kan der alligevel skitseres nogle bidrag til en forståelse.

Først og fremmest viser gennemgangen af historien, at der i næsten 50 år har været en bestræbelse i retning af en stærkere koordinering og overordnet ledelse. I så henseende er etableringen af direktioner en fortsættelse af en udvikling, der var i gang, og som muligvis ville have fortsat, også uden reform. Men kommunalreformen kan godt have fremmet udviklingen. Om det er tilfældet, er 
belyst i tabel 14, der viser, om kommunalreformskommuner med større sandsynlighed har en direktion end kommuner, hvis grænser ikke blev ændret.

Tabel 14. Direktion og kommunalreform. \% lodret

\begin{tabular}{|l|l|l|l|}
\hline & Ikke kommunalreform & Kommunalreform & Sum \\
\hline Forvaltningsmodel & 57.14 & 45.88 & 49.61 \\
\hline Direktionsmodel & 42.86 & 54.12 & 50.39 \\
\hline Sum & 100.00 & 100.00 & 100.00 \\
\hline
\end{tabular}

$C h i^{2}=2.8517, \mathrm{p}=0.091$

Der er en svag og lige akkurat signifikant $(\mathrm{p}<0,10)$ tendens til, at kommunalreformskommuner $\mathrm{i}$ højere grad anvender en direktionsmodel. En nærliggende forklaring er, at reformen gjorde det lettere at gennemføre ændringer også af organisationen, da der under alle omstændigheder skulle tages stilling til ledelsen af kommunen. Beskrivelsen af dagens organisation og den empiriske analyse viser da også en betydelig overensstemmelse med kommunalreformens hensigter om bedre overordnet styring.

Men heri ligger der også et paradoks. Hvis reformen lagde så stor vægt på styring og koordinering, og hvis der faktisk kan vises en vej til en bedre styring, hvorfor arbejder mange kommuner så stadig inden for rammerne af en forvaltningsmodel, om end den ofte er forklædt? Hvorfor har alle ikke valgt en direktionsmodel? Svaret kan hentes to steder. Det ene er hos den sociologiske institutionalisme, der heri vil se en bekræftelse af organisationers træghed over for dramatiske ændringer, initieret fra toppen. Den anden (som måske er en variant heraf) må søges i den kendsgerning, at reformen med omhu bevarede udvalgsstyret. Og hvordan man end vender og drejer det, er der også i den teoretiske litteratur - grundlag for at formode, at en direktion vil svække udvalgene, hvilket disse næppe er begejstrede for. Den sidstnævnte tolkning bekræftes af, at det tilsyneladende har været meget lettere at decentralisere end at etablere en stærk overordnet ledelse. Decentraliseringen er ikke på samme måde nogen trussel mod udvalgene.

På denne måde er konklusionen, at kommunalreformen har præget den organisatoriske udvikling i kommunerne. Det gælder både den del af den, der betød store ændringer (størrelse og opgaver) og den del af den, der betød kontinuitet - udvalgsstyret. 
Bilag 1. Oversigt over variable.

\begin{tabular}{|c|c|c|c|c|}
\hline Variabelnavn & Definition & Kilde & Gennemsnit & $\begin{array}{l}\text { Standardaf- } \\
\text { vigelse }\end{array}$ \\
\hline \multicolumn{5}{|l|}{ Intervalskalerede } \\
\hline Budgetteret driftsres. & $\begin{array}{l}\text { Budgetteret skattefinansieret driftsresultat i } \\
\text { danske kroner per indbygger }\end{array}$ & KORA & 1671.071 & 1048.982 \\
\hline Realiseret driftsres. & $\begin{array}{l}\text { Realiseret skattefinansieret driftsresultat i } \\
\text { danske kroner per indbygger }\end{array}$ & KORA & 2618.128 & 1283.414 \\
\hline Udgiftspres (budget) & $\begin{array}{l}\text { Udgiftspres, budgetteret (Udgiftsbehov divi- } \\
\text { deret med budgetterede indtægter fra skatter } \\
\text { og tilskud) }\end{array}$ & $\begin{array}{l}\text { Indenris- } \\
\text { ministeriets } \\
\text { nøgletal }\end{array}$ & 1.000067 & .0434843 \\
\hline $\begin{array}{l}\text { Udgiftspres } \quad \text { (regn- } \\
\text { skab) }\end{array}$ & $\begin{array}{l}\text { Udgiftspres, faktisk (udgiftsbehov divideret } \\
\text { med de regnskabsførte indtægter fra skatter og } \\
\text { tilskud) }\end{array}$ & $\begin{array}{l}\text { Indenrigs- } \\
\text { ministeriets } \\
\text { nøgletal }\end{array}$ & .9958674 & .0426269 \\
\hline Indt.ændr. (budget) & $\begin{array}{l}\text { Indtægtsændringer per indb, budgetteret. } \\
\text { Ændringer i summen af indtægter fra skatter } \\
\text { og tilskud i forhold til året før }\end{array}$ & KORA & 1385.533 & 1257.547 \\
\hline Indt.ændr. (regnskab) & Indtægtsændringer per indb, faktisk & KORA & 1161.234 & 1097.696 \\
\hline Lnindb & Ln af kommunens indbyggertal & $\begin{array}{l}\text { Indenrigs- } \\
\text { ministeriets } \\
\text { nøgletal }\end{array}$ & 10.64387 & .7895873 \\
\hline Likv. året før & Likviditet året før per indb & KORA & 4540.894 & 2538.824 \\
\hline Borgm.andel & $\begin{array}{l}\text { Borgmesterpartiets } \\
\text { mandatandel mellem } 0 \text { og } 1 .\end{array}$ & $\begin{array}{l}\text { Danmarks } \\
\text { Statistik }\end{array}$ & .3699592 & .1231124 \\
\hline \multicolumn{5}{|l|}{ Dummyvariable } \\
\hline Direktion (dummy) & $\begin{array}{l}\text { Ren og modificeret forvaltningsmodel er } \\
\text { kodet } 0 \text {, mens ren og modificeret direktions- } \\
\text { model er kodet } 1 \text { (se tabel } 10 \text { ). }\end{array}$ & & & \\
\hline Øk.mål (dummy) & $\begin{array}{l}\text { Har kommunen en økonomisk målsætning? } \\
\text { (1: Konkrete definerede, } 0 \text { : ingen mål eller } \\
\text { ikke kvantificerede mål) }\end{array}$ & Survey & & \\
\hline Ramme (dummy) & $\begin{array}{l}\text { Har kommunen en økonomisk ramme for } \\
\text { såvel de samlede udgifter som for det enkelte } \\
\text { udvalgs udgifter? (1: Ramme for både det } \\
\text { samlede budget og de enkelte områder, } 0 \text { : } \\
\text { Ingen ramme eller kun samlet ramme) }\end{array}$ & Survey & & \\
\hline Decentr. (dummy) & $\begin{array}{l}\text { Decentralisering målt ved adgangen til at } \\
\text { videreføre bevillinger ( } 1 \text { : Der er regler for } \\
\text { overførsel af bevillinger som aldrig fraviges, } \\
0 \text { : Andre svar) }\end{array}$ & Survey & & \\
\hline Målstyring (dummy) & $\begin{array}{l}\text { Målstyring på institutioner (1: Der er opstillet } \\
\text { konkrete mål i budgettet, } 0: \text { Ingen mål eller } \\
\text { generelt formulerede mål) }\end{array}$ & Survey & & \\
\hline
\end{tabular}




\section{Litteratur}

Balle Hansen, Morten. 1998, Chefgruppemødet- fra informationsformidling til kollektiv ledelse? Politica.

Blom-Hansen, Jens. 2002, Budget Procedures and the Size of the Budget: Evidence from Danish Local Government, Scandinavian Political Studies.

Blom Hansen, Jens (red). 2012, Fra sogn til velfcerdsproducent.

Bækgaard, Martin; Thomas Frank og Søren Serritzlew. 2009, Ceremoni eller strategi? Reformers formål og sideformål. Politica, 41. årg. nr. 2 2009, 215-230.

Bækgaard, Martin. 2010, Udvalgsmedlemskab, organisering og praferencer.

Bækgaard, Martin. 2011, The Impact of Formal Organizational structure on Politico-administrative Interaction. Evidence from a Natural Experiment, Public Administration.

Bækgaard, Martin. 2013, Afhænger politikernes indflydelse af den administrative organisering? Anvendelsen af direktions- og forvaltningsmodeller i de danske kommuner, Politica.

Christoffersen, Henrik og Kurt Klaudi Klausen. 2012, Den danske kommunekonstruktion.

Dietrichson, Jens og Lina Maria Ellegård. 2012, Institutions promoting fiscal discipline: evidence from Swedish municipalities, Lunds Universitet.

Ejersbo, Niels. 1998, Kommunale strukturer - et studie i lokal variation, Politica.

Flohr Nielsen, Jørn. 1985, Kommunal organisering.

Grønnegaard Christensen, Jørgen. 1998, Det kommunale mikrokosmos, Politica.

Hammond, Thomas. 1986, Agenda Control, Organizational Structure, and Bureaucratic Politics, American Journal of Political Science.

Hammond, Thomas and Jack Knott. 1996, Who Controls the Bureaucracy? : Presidential Power, Congressional Dominance, Legal Constraint, and Bureaucratic Autonomy in a Model of MultiInstitutional Policy-Making. Journal of Law, Economics, \& Organization, Vol. 12, No. 1

Hansen, Karin m.fl. 2008, Nye kommuner i støbeskeen.

Houlberg, Kurt og Kræn Blume Jensen. 2010, Kommunernes økonomiske situation og udgiftspolitiske prioriteringer. København: AKF.

Klausen, K.K. 2014, Strategisk ledelse i det offentlige, fremskrive, forudse, forestille.

March, James og Johan P. Olsen. 1989, Rediscovering Institutions.

Mouritzen, Poul Erik. 1990, Den politiske cyklus, Politica.

Ryom Villadsen, Anders. 2013, Når kommuner organiserer i takt. Institutionelle forklaringer på forvaltningsændringer fra 1984-2000, Politica nr. 2. 